\title{
Occlusal assessment in surgically assisted unilateral cleft lip and palate patients
}

\author{
Leanne Matias Portela Leal', Marcus Vinicius Neiva Nunes do Rego², Cosme José Albergaria da Silva Filho³, \\ Leopoldino Capelozza Filho ${ }^{4}$, Mauricio de Almeida Cardoso ${ }^{5}$
}

Objective: The aim of this study was to assess the magnitude of occlusal changes in individuals with unilateral cleft lip and palate (CLP). The study was conducted on study casts of 25 subjects, 14 men and 11 women aged from 7 to 20 years, without previous orthodontic treatment and with surgical repair carried out at São Marcos Hospital, Teresina, Piauí State, Brazil. Methods: The casts were assessed by three orthodontists based on the occlusal scores established by Atack et al., whose scores range from 1 to 5, according to the magnitude of transverse and sagittal changes. Results: Intra and inter-observer reproducibility of occlusal scores was satisfactory and statistically significant according to the Spearman Correlation test with significance level set at 5\%. With regard to the distribution of occlusal scores, $30.67 \%$ of the subjects achieved scores 1 and 2, 22\% score 3 and $47.53 \%$ achieved scores 4 and 5. Conclusions: Four was the score most frequently assigned by the observers, disclosing a high degree of transverse and sagittal disorders in the occlusion of patients.

Keywords: Growth. Malocclusion. Cleft lip.

Objetivo: o propósito do presente estudo foi avaliar a magnitude das alterações oclusais em 25 indivíduos com fissura transforame incisivo unilateral, sendo 14 do sexo masculino e 11 do sexo feminino, com idades entre 7 e 20 anos, não tratados ortodonticamente e operados no Hospital São Marcos, na cidade de Teresina/PI. Métodos: os modelos de estudo desses pacientes foram avaliados por três ortodontistas, utilizando-se como referência os índices oclusais de Atack et al., cujos escores variam de 1 a 5 , de acordo com a magnitude das alterações transversais e anteroposteriores. Resultados: os níveis de confiabilidade e reprodutibilidade do índice oclusal intraexaminador e interexaminadores, respectivamente, mostraram-se bastante satisfatórios e estatisticamente significativos quando aplicado o teste de correlação de Spearman, com intervalo de confiança de 5\%. Quanto à distribuição dos índices oclusais, 30,67\% dos indivíduos apresentaram os índices 1 e 2; 22\% o índice 3; e 47,53\% os índices 4 e 5 . Conclusão: o índice oclusal 4 foi o mais referido, de acordo com todos os escores atribuídos pelos examinadores, evidenciando um acentuado grau de alterações transversais e anteroposteriores na oclusão dos pacientes.

Palavras-chave: Crescimento. Má oclusão. Fenda labial.

\footnotetext{
${ }^{1}$ Masters student in Orthodontics, Sacred Heart University (USC).

${ }^{2}$ Professor of Orthodontics at the Graduate and Postgraduate programs, UNINOVAFAPI. Professor of Orthodontics at the Postgraduate program, Federal University of Piauí (UFPI).

${ }^{3}$ Graduated in Dentistry, UNINOVAFAPI.

${ }^{4} \mathrm{PhD}$ in Orthodontics, College of Dentistry - Bauru/USP. Professor of Orthodontics at the Graduate and Postgraduate (specialization and Masters courses) programs, USC.

${ }^{5} \mathrm{PhD}$ in Orthodontics, State University of São Paulo (UNESP). Professor of Orthodontics at the Graduate and Postgraduate (specialization and Masters courses) programs, USC.
}

\begin{abstract}
How to cite this article: Leal LMP, Rego MVNN, Silva Filho CJA, Capelozza Filho L, Cardoso MA. Occlusal assessment in surgically assisted unilateral cleft lip and palate patients. Dental Press J Orthod. 2013 July-Aug;18(4):120-5.
\end{abstract}

Submitted: May 18, 2011 - Revised and accepted: February 15, 2012

" The authors report no commercial, proprietary or financial interest in the products or companies described in this article.

Contact address: Mauricio de Almeida Cardoso

Rua Arnaldo de Jesus Carvalho Munhoz, 6-100 - Bauru/SP, Brazil

CEP: 17018-520 -E-mail: maucardoso@uol.com.br 


\section{INTRODUCTION}

Individuals with cleft lip and palate exhibit functional and morphological changes and may, in some cases, manifest psychosocial changes given that the affected region is highly visible, causing a negative esthetic impact. As for their morphological diversity, lip and palate clefts yield different levels of severity and consequences, requiring not only changes in treatment protocol, but also an interdisciplinary team composed of an orthodontist, pediatrician, plastic surgeon, speech pathologist, psychologist, geneticist and social worker, to promote adequate esthetic and functional rehabilitation as well as seamless social and psychological integration to patients. ${ }^{6}$

In Brazil, clefts are currently classified on the basis of a system proposed by Spina, ${ }^{18}$ which uses the incisive foramen, the only single structure connecting the primary and secondary palates during intrauterine life, as anatomical reference. These palates ultimately formed the midface. Thus, this classification defines clefts based on length, in line with their embryonic origin. ${ }^{17}$ According to this classification, clefts are divided into four different groups: Group I = Pre-foramen clefts; Group II = Trans-foramen incisor clefts; Group III = Post-foramen incisor clefts; and Group IV $=$ Rare facial clefts. ${ }^{14}$

Some treatments should be provided as soon as patients with this anomaly are born in order to improve the quality of life of these individuals. Soon after the third month of life, the lip should be reconstructed (cheiloplasty) and in the twelfth month, the palate should be reconstructed (palatoplasty). These surgeries are called primary surgeries as they are aimed at restoring the anatomic integrity left unfinished in intrauterine life. If necessary, secondary surgeries are performed to close the fistulas, as well as pharyngoplasty while finishing touches are applied to the primary surgeries.

The craniofacial growth of individuals with unilateral cleft lip and palate (CLP) should be constantly monitored due to the adverse effects of primary surgeries on the anteroposterior and transverse growth of the maxilla. Some changes in the occlusion are frequently found, especially anterior crossbite and posterior crossbite. ${ }^{12}$

The impact of primary plastic surgery on the midface growth makes it important to study the magni- tude of occlusal changes undergone by patients with unilateral cleft lip and palate (CLP) subjected to surgery at São Marcos Hospital in Teresina, Piauí State (PI), Brazil, an institution recognized by the Ministry of Health as a reference center in the Northeastern region of Brazil.

\section{MATERIAL AND METHODS}

\section{Sample characterization}

The NOVAFAPI Institutional Review Board (CEP/NOVAFAPI) reviewed this research project and found that it met the provisions of resolution No. 196/96, issued by the National Council of Health (CNS/MS). Therefore, the project was authorized and filed under number 0430-08.

The sample comprised 25 individuals aged from 7 to 20 years old, with unilateral CLP, subjected to primary plastic surgery at the São Marcos Hospital in the city of Teresina, Piauí State, Brazil. Out of 25 patients who participated in this study, 14 (56\%) were men while 11 (44\%) women. Patients' age range was 14 years and 3 months (Table 1). According to the number of primary plastic surgeries and the time when they were performed, the first lip repair was carried out by means of the Millard's technique, on average, when the patient was 7 months old; whereas

Table 1 - Mean, median and standard deviation of ages (in years) of patients with unilateral CLP who underwent surgery at São Marcos Hospital. Data displayed according to sex.

\begin{tabular}{ccc}
\hline Sex & Mean \pm standard deviation & Median \\
\hline Feminine & $14.24 \pm 5.97$ & 14.00 \\
\hline Masculine & $14.23 \pm 3.55$ & 15.00 \\
\hline TOTAL & $14.25 \pm 5.30$ & 15.00 \\
\hline
\end{tabular}

Table 2 - Distribution of the 25 patients with unilateral CLP who underwent surgery at São Marcos Hospital. Data displayed according to the number of surgeries and the time when the first plastic surgeries were performed (in months).

\begin{tabular}{ccc}
\hline Surgery & $\begin{array}{c}\text { Mean } \pm \text { standard deviation } \\
\text { Number of procedures }\end{array}$ & Median \\
\hline cheiloplasty & $1.29 \pm 0.62$ & 1.00 \\
\hline palatoplasty & $1.29 \pm 0.62$ & 1.00 \\
\hline $1^{\text {st }}$ cheiloplasty & Age (months) & 3.00 \\
\hline $1^{\text {st }}$ palatoplasty & $7.63 \pm 8.24$ & 20.00 \\
\hline
\end{tabular}


palatoplasty was performed at 30 months of age, using a modified version of Von Langenback's technique (Table 2).

The following inclusion criteria were applied: Plastic surgeries performed at São Marcos Hospital; cheiloplasty (lip surgery) before 2 years of age; palatoplasty (surgery of the palate) before 3 years of age; no prior orthopedic treatment performed to achieve expansion and/or reverse traction of the maxilla; no syndrome in the craniofacial region; no alveolar bone graft in the cleft area.

\section{Assessment of occlusal characteristics in the study casts}

The occlusal characteristics of the 25 patients with unilateral CLP were evaluated on study casts (Fig 1) by 3 examiners (orthodontists and professors at the NOVA-
FARI Specialization Course in Orthodontics) using the occlusal index proposed by Atack et al. ${ }^{2}$ (Table 3 ).

The casts were carefully arranged in ascending order on a bench concealing the patients' personal identification data. This evaluation was performed individually with no communication between examiners, who were previously calibrated for application of the occlusal index, while changing the numbering on the casts in both assessments to prevent memorization.

In order to verify method reliability, all casts were reassessed 15 days after the first evaluation. ${ }^{8}$

\section{Statistical analysis \\ Method reliability}

Evaluation results were exported to a database created with SPSS software, version 13.0. Inter-examiner correlation was determined in both assessments
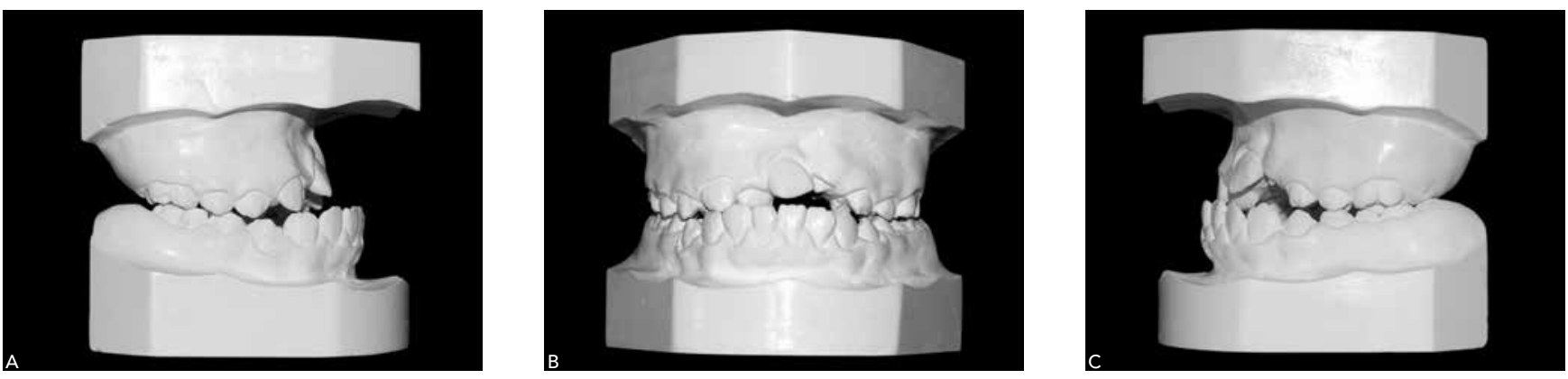

Figure 1 - Study casts of an individual from the sample used in this study, showing unilateral CLP. A) Right lateral view. B) Frontal view. C) Left lateral view.

Table 3 - Evaluation index of the occlusal characteristics using casts (inter-arch relationship) in individuals with unilateral CLP. ${ }^{3}$

\begin{tabular}{|c|c|c|}
\hline Group & Occlusal characteristics & $\begin{array}{c}\text { Long-term outcome } \\
\text { prognosis }\end{array}$ \\
\hline 1 & $\begin{array}{l}\text { - Positive overjet with normal inclination or lingual inclination of the incisors; } \\
\text { - Absence of crossbite and open bite; } \\
\text { - Satisfactory morphology of the upper dental arch }\end{array}$ & Excellent \\
\hline 2 & $\begin{array}{l}\text { - Positive overjet with normal inclination or labial inclination of the incisors; } \\
\text { - Unilateral crossbite / tending towards crossbite; } \\
\text { - Tendency towards open bite adjacent to the cleft }\end{array}$ & Good \\
\hline 3 & $\begin{array}{l}\text { - End-on relationship with normal inclination or labial inclination of the incisors, or negative overjet with incisors } \\
\text { inclined lingually; } \\
\text { - Tendency towards open bite adjacent to the cleft }\end{array}$ & Regular \\
\hline 4 & $\begin{array}{l}\text { - Negative overjet with normal inclination or labial inclination of the incisors; } \\
\text { - Tendency towards unilateral/bilateral crossbite; } \\
\text { - Tendency towards open bite adjacent to the cleft }\end{array}$ & Bad \\
\hline 5 & $\begin{array}{l}\text { - Negative overjet with labial incisor inclination } \\
\text { - Bilateral crossbite; } \\
\text { - Substantially changed upper jaw morphology }\end{array}$ & Very bad \\
\hline
\end{tabular}


(initial and after 15 days), as well as intraexaminer correlation with the purpose of verifying method reliability using Spearman's correlation test with a significance level set at 5\% ( $<<0.05)$.

To define the degree of agreement, the scale proposed by Altman ${ }^{2}$ was applied to the values shown in Table 4. Only "good" and "very good" scores were considered satisfactory.

Table 4 - Relevance of the level of agreement as described by Altman. ${ }^{2}$

\begin{tabular}{cc}
\hline Value & Level of agreement (LA) \\
\hline$\leq 0.2$ & Poor \\
0.21 to 0.40 & Regular \\
0.41 to 0.60 & Mild \\
0.61 to 0.80 & Good \\
0.81 to 1.00 & Very good \\
\hline
\end{tabular}

Table 5 - Intraobserver agreement in determining the occlusal index in the 25 patients with unilateral CLP who underwent surgery at São Marcos Hospital. Teresina, Piauí State, Brazil.

\begin{tabular}{cccc}
\hline & \multicolumn{3}{c}{ Correlation } \\
\cline { 2 - 4 } Examiner & $\mathbf{P}$ & $\mathbf{R}$ & LA \\
\hline Orthodontist 1 & $0.000 *$ & 0.896 & VG \\
Orthodontist 2 & $0.000 *$ & 0.627 & G \\
Orthodontist 3 & $0.000 *$ & 0.917 & VG \\
\hline
\end{tabular}

Spearman correlation. $N=25,{ }^{*}$ significant at $p<0.05$

Captions for Level of Agreement: P - Poor, M - Mild, R - Regular, G - Good, VG - Very good.

$\mathrm{P}$ column = correlation between the first and second score assigned to each observer. $\mathrm{R}$ column = correlation for all examiners.

\section{RESULTS}

Intra and inter-observer agreement in determining the occlusal index

Table 5 depicts a correlation between the first and second scores assigned to each observer (p), and shows whether the degree of agreement is acceptable. A statistically significant correlation (R) was found for all examiners.

As regards inter-observer correlation, the degree of agreement ranged between "good" and "very good" (Table 6). The good repeatability accomplished in the test was expected because all examiners were orthodontists and the index designed by Atack et $\mathrm{al}^{3}$ proved to be easy to apply.

\section{Magnitude of occlusal changes exhibited by the patients with CLP}

The results showed that $30.67 \%$ of patients were included in indices 1 and 2, 22\% in index 3, and 47.33\% were included in indices 4 and 5 (Fig 2).

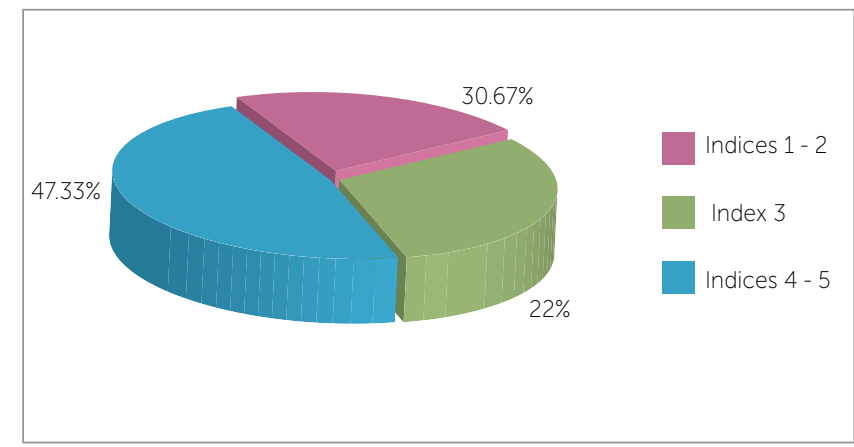

Figure 2 - Distribution of occlusal indices in the 25 patients with unilateral CLP who underwent surgery at São Marcos Hospital.

Table 6 - Inter-observer agreement in the first and second evaluations in determining the occlusal index in the 25 patients with unilateral CLP who underwent surgery at São Marcos Hospital.

\begin{tabular}{|c|c|c|c|c|c|c|c|c|c|}
\hline \multirow{2}{*}{$\begin{array}{l}\text { Examiner } \\
1^{\text {st }} \text { Evaluation }\end{array}$} & \multicolumn{3}{|c|}{ Orthodontist 1} & \multicolumn{3}{|c|}{ Orthodontist 2} & \multicolumn{3}{|c|}{ Orthodontist 3} \\
\hline & $p$ & $\bar{R}$ & LA & $p$ & $\bar{R}$ & LA & $p$ & $\bar{R}$ & LA \\
\hline Orthodontist 1 & - & - & & $0.000^{*}$ & 0.667 & G & $0.000^{*}$ & 0.785 & $G$ \\
\hline Orthodontist 2 & $0.000 *$ & 0.667 & G & - & - & - & $0.000^{*}$ & 0.809 & VG \\
\hline Ortodontist 3 & $0.000 *$ & 0.785 & $G$ & $0.000 *$ & 0.809 & $V G$ & - & - & - \\
\hline \multirow{2}{*}{$\begin{array}{c}\text { Examiner } \\
2^{\text {nd }} \text { Evaluation }\end{array}$} & \multicolumn{3}{|c|}{ Orthodontist 1} & \multicolumn{3}{|c|}{ Orthodontist 2} & \multicolumn{3}{|c|}{ Orthodontist 3} \\
\hline & $p$ & $R$ & LA & $p$ & $\mathbf{R}$ & LA & p & $\mathbf{R}$ & LA \\
\hline Orthodontist 1 & - & - & - & $0.000^{*}$ & 0.700 & G & $0.000^{*}$ & 0.892 & $V G$ \\
\hline Orthodontist 2 & $0.000 *$ & 0.700 & G & - & - & - & $0.000^{*}$ & 0.651 & G \\
\hline Orthodontist 3 & $0.000 *$ & 0.892 & VG & $0.000 *$ & 0.651 & G & - & - & - \\
\hline
\end{tabular}

Spearman correlation. $N=25$, *significant at $\mathrm{p}<0.05$. LA (Level of Agreement): P - Poor, M - Mild, R - Regular, BG- Good, VG - Very good. $\mathrm{P}$ column $=$ correlation between the first and second score assigned to each observer. $\mathrm{R}$ column $=$ correlation for all examiners. 


\section{DISCUSSION}

Lip and palate clefts are a congenital defect with diverse clinical manifestations. Its involvement can range from a small notch in the lip vermilion or mucosa of the uvula to a complete breakdown of the maxilla. In summary, from an embryonic point of view, clefts can affect the primary and secondary palate with different levels of severity. Given their higher prevalence, this study aimed at assessing the behavior of post-surgical complete unilateral clefts involving the primary and secondary palate, also known as unilateral cleft lip and palate (CLPs). Corroborating the literature, ${ }^{3}$ this study also showed a higher prevalence of unilateral CLP in males.

According to surveys conducted at the Hospital for Rehabilitation of Craniofacial Anomalies (HRACUSP), these clefts account for approximately 33\% of occurrences. ${ }^{16}$ Among unilateral CLPs, there are numerous variables that influence their anatomical configuration and differentiate one patient from another, such as cleft width, the presence of Simonart's band and degree of nose asymmetry. Simonart's band is formed by a bridge of soft tissue that joins the mesial and distal edges of a complete lip and palate cleft, which can positively affect the morphology of postoperative upper dental arches when the band is bulky. ${ }^{11}$

Primary plastic surgery reconstructs lesions in the lip and palate and in so doing influences the behavior of the nasomaxillary complex, of which expression of genetic growth potential is restricted. The more numerous the morphological variables inherent in clefts are, the greater will be the number of therapeutic variables that may influence the patient's face and occlusion in the long-term. Among these variables, one could mention the amount of time required to complete surgery, surgical techniques, number of repetitive surgeries as well as the extra-surgical care provided pre- and postoperatively. Undoubtedly, the surgeon's skill in manipulating young tissue plays a key role in ultimately shaping the face..$^{11,13,14}$

The current surgical protocol adopted at São Marcos Hospital recommends the performance of lip repair at 6 months of postnatal life and palatoplasty at 18 months. However, the protocol used at the Hospital for Rehabilitation of Craniofacial Anomalies (HRACUSP) recommends that such procedures be carried out at 3 and 12 months of postnatal life, respectively. ${ }^{11}$
Choosing a straightforward occlusal index is of paramount importance since it interferes in method reliability and in determining the number of examiners. The results of this study agree with those of Okada, ${ }^{11}$ who also found the occlusal index of Atack et al. ${ }^{3}$ to be straightforward and easy to apply, since there was no statistically significant intraobserver differences, even when different groups of examiners were used, such as oral maxillofacial surgeons, plastic surgeons and orthodontists. Therefore, the ease with which the occlusal assessment method was applied precluded the need for a greater number of examiners.

The quality of a given rehabilitation protocol used by a reference center in treating patients with cleft lip and palate can be measured by the magnitude of occlusal changes that occur, especially in patients with CLP, since sequelae inherent to the morphology of the clefts as a result of the surgical repair procedure, involve significant changes in the transverse and anteroposterior growth of the maxilla. Results showed that cases considered "very bad" (indices 4 and 5) accounted for almost half of the sample, confirming the negative effect of primary plastic surgery in the growth of midface structures, for which there seems to be consensus in the literature. , $^{1,5,9-12}$

On assessing the magnitude of occlusal alterations observed in patients rehabilitated at São Marcos Hospital (Teresina, Piauí State), this magnitude was found to be close to results achieved by reference centers both in Brazil and abroad - such as the Hospital for Rehabilitation of Craniofacial Anomalies, Bauru, São Paulo State, and the Rehabilitation Center of Oslo, Norway. The indices found in this study were compared to those obtained by Okada, ${ }^{11}$ which were assessed by the Bauru and Oslo centers. For indices 1 and 2, the data showed a percentage of $30.67 \%$ in Teresina, 34\% in Bauru and $60 \%$ in Oslo. As for index 3, the percentage was $22 \%$ in Teresina, 27.72\% in Bauru and 22\% in Oslo. For indices 4 and 5 (which represent the major occlusal sequelae and comprise the cases requiring orthognathic surgery) the percentages were $47.33 \%$ in Teresina, $38.20 \%$ in Bauru and 18\% in Oslo. Thus, it can be asserted that the Oslo Center results were higher than those of the Brazilian centers, especially when comparing the percentage of cases with greater occlusal sequelae.

With regard to the average occlusal index based on all scores assigned by examiners in both assessments, 
there was an index of 3.28 in Teresina, 3.07 in Bauru and 2.52 in the Oslo Center. In examining the median scores assigned by examiners in the present study, index 4 proved to be the most frequent, indicating a high degree of transverse and anteroposterior changes in the occlusion of the patients.

How can one explain Oslo's higher results in terms of occlusion conditions? Many variables certainly play a role in the diversity of the outcomes, but according to Shaw et al. ${ }^{13}$ one major factor is the standardization of the protocol and the surgical techniques adopted, along with a small number of surgeons, with surgeries being performed by virtually one single surgeon.

When the results obtained in Teresina were compared to those of Bauru, a higher percentage of cases with greater occlusal sequelae were found in Teresina. However, age is yet another key factor to be taken into account when interpreting these results. The vast majority of patients in this study were at the permanent dentition stage, whereas those assessed by $\mathrm{Okada}^{11}$ in Bauru were at the early mixed dentition stage. Given that plastic surgery cumulatively affects the growth of the midface, patients at the stage of occlusal maturity tend to produce more sequelae in transverse and anteroposterior maxillary growth compared to younger patients. It is worth noting that variables such as the anatomical extent of the cleft, the presence of Simonart's band, surgical procedure variables such as the surgical technique, surgeon skills and pre and postoperative care were not assessed.

The findings of this study confirmed the assumption that the maxillomandibular relationship of a patient with cleft lip and palate undergoes - starting from the stage of embryo formation - the strains imposed by the cleft and the resulting functional deviations. Furthermore, maxillomandibular relationship is potentially undermined by reconstructive surgeries (lip repair and palatoplasty), which hinder maxillary growth to varying degrees, resulting in changes in craniofacial growth and deficiencies in the intra and inter-arch relationships.

\section{CONCLUSIONS}

"With regard to the magnitude of occlusal changes, it was found that $30.67 \%$ of the subjects exhibited indices 1 and 2, 22\% index 3 and 47.53\% exhibited indices 4 and 5 .

" On examining the scores assigned by examiners, occlusal index 4 proved to be the most frequent, indicating a high degree of transverse and anteroposterior changes in the occlusion of the patients.
1. Aiello CA, Silva Filho OG, Freitas JAS. Fissuras labiopalatais: uma visão contemporânea do processo reabilitador. In: Mugayar LRF, colaboradores. Pacientes portadores de necessidades especiais. Manual de odontologia e saúde bucal. São Paulo: Pancast, 2000. p. 111-39.

2. Altman DG. Practical statistics for medical research. p. 403-409. London: Chapman \& Hall; 1991

3. Atack N, Hathorn IS, Semb G, Dowell T, Sandy JR. A new index for assessing surgical outcome in unilateral cleft lip and palate subjects aged five: reproducibility and validity. Cleft Palate Craniofac J. 1997:34(3):242-6.

4. Capelozza Filho L, Cavassan AO, Silva Filho OG. Avaliação do crescimento craniofacial em portadores de fissuras transforame incisivo unilateral. Estudo transversal. Rev Bras Cirur. 1987;77(2):97-106.

5. Cavassan AO, Silva Filho OG. Abordagem ortodôntica. In: Trindade IEK, Silva Filho OG. Fissuras labiopalatinas: uma abordagem interdisciplinar. São Paulo: Ed. Santos; 2007. cap. 4, p. 213-38.

6. Correia JP, Carvalho LRR, Rego MVNN. Fissuras labiais. In: Carreirão S. Cirurgia plástica. São Paulo: Atheneu; 2005. p. 220-30.

7. Faraj JORA, André M. Alterações dimensionais transversas do arco dentário com fissuras labiopalatinas, no estágio de dentadura decídua. Rev Dental Press Ortod Ortop Facial. 2007;12(5):100-8.

8. Gravely JF, Benzies PM. The clinical significance of tracing error in cephalometry. Br J Orthod. 1974;1(3):95-101.

9. Houston WJ. The analysis of errors in orthodontic measurements. Am J Orthod. 1983;83(5):382-90.

10. Mazzottini R. Variações nas dimensões do arco dentário superior em fissurados unilaterais, em função da época do tratamento cirúrgico [tese]. Bauru (SP): Universidade de São Paulo; 1985.
11. Okada TO. Avaliação dos efeitos da queiloplastia e palatoplastia primária sobre o crescimento dos arcos dentários de crianças com fissura transforame incisivo unilateral dos 5-6 anos de idade [tese]. Araraquara (SP): Universidade Estadual Paulista; 2001; 205 p.

12. Ribeiro AA, Leal L, Thuin R. Análise morfológica dos fissurados de lábio $e$ palato do centro de tratamento de anomalias craniofaciais do Estado do Rio de Janeiro. Rev Dental Press Ortod Ortop Facial. 2007:12(5):109-18.

13. Mars M, Asher-McDade C, Battström V, Dahl E, McWilliam J, Molsted K, et al. A six-centre international study of treatment outcome in patients with clefts of the lip and palate: Part 3. Dental arch relationships. Cleft Palate Craniofac J. 1992;29:405-408

14. Silva Filho OG. Crescimento facial. In: Trindade IEK, Silva Filho OG. Fissuras labiopalatinas: uma abordagem interdisciplinar. São Paulo: Ed. Santos; 2007. p. 173-98.

15. Silva Filho OG, Freitas JAS. Caracterização morfológica e origem embrionária. In: Trindade IEK, Silva Filho OG. Fissuras labopalatinas: uma abordagem interdisciplinar. São Paulo: Ed. Santos; 2007. p. 17-49.

16. Silva Filho OG, Freitas JAS, Okada T. Fissuras labiopalatais: diagnóstico e uma filosofia interdisciplinar de tratamento. In: Pinto VG. Saúde bucal coletiva. $4^{a}$ ed. São Paulo: Ed. Santos; 2000. p. 481-527.

17. Silva Filho $O G$, Ferrari Júnior FM, Rocha DL, Freitas JAS. Classificação das fissuras labiopalatais: breve histórico, considerações clínicas e sugestão de modificação. Rev Bras Cir. 1992;82(2):59-65.

18. Spina V, Psillakis JM, Lapa FS, Ferreira MC. Classificação das fissuras lábio-palatinas: sugestão de modificação. Rev Hosp Clin Fac Méd. 1972:27(1):5-6. 